\title{
Sustainable Recruitment: Individual Characteristics and Psychosocial Working Conditions Among Swedish Police Officers'
}

I Stefan Annell ${ }^{2}$

PhD/Post doc researcher, Stockholm University, Department of Psychology

\section{Petra Lindfors}

Professor, Stockholm University, Department of Psychology

\section{Göran Kecklund}

Professor, Stockholm University, Stress Research Institute

\section{Magnus Sverke}

Professor, Stockholm University, Department of Psychology

\begin{abstract}
Selection research has typically focused on how to identify suitable candidates, while less is known regarding the long-term effects of various selection factors once the suitable candidates have started working. The overall aim of this study was to examine the relative importance of selection factors (measured during recruitment), and psychosocial working conditions (once candidates started working) for four outcomes, namely (I) job satisfaction, (2) organizational citizenship behavior, (3) occupational retention, and (4) health. Data came from a longitudinal study of newly hired police officers in Sweden ( $N=508$ ), including recruitment data and a follow-up after 3.5 years. Results of hierarchical multiple regression analyses showed that psychosocial working conditions were more important than selection factors in predicting the four outcomes. The findings suggest that employers, to ensure sustainability, need to focus on activities that facilitate newcomers' entering in the organization and their professions by providing a sound work climate.
\end{abstract}

\section{KEYWORDS}

health outcomes / individual characteristics / police / recruitment / selection / sustainability / work demands / work socialization

he last decades have seen a growing interest in various aspects of sustainability. In the Nordic countries, ideas regarding sustainability have also come to address different facets of the working life (Abrahamsson \& Johansson 2013; Kira et al. 2010). Despite the increasing interest, there is still no established definition of sustainability within working life. However, researchers have typically included a holistic approach

\footnotetext{
${ }^{1}$ You can find this text and its DOI at https://tidsskrift.dk/njwls/index.

${ }^{2}$ Corresponding author: Stefan Annell, Stockholm University, Department of Psychology, SE-106 91 Stockholm, Sweden. E-mail: stefan.annell@psychology.su.se
} 
with simultaneous concerns for economy, efficiency, human growth, and well-being along with long-term outcomes at different levels, including levels of the individual, organization, and society (Di Fabio 2017; Eriksson et al. 2017).

While research on sustainability in working life often has claimed to apply a holistic approach, few studies have aimed to integrate a focus on recruitment of new personnel with that of psychosocial working conditions. The present study sets out to address this gap by examining the relative importance of selection factors (individual characteristics such as personality) and psychosocial working conditions for outcomes of importance for a sustainable working life. This was investigated in a cohort of newly hired police officers in Sweden, by combining recruitment data with data from a follow-up survey.

For employers, the costs of recruiting and training new personnel can be high (Casio \& Boudreau 2010; Griffeth \& Hom 2001). This is obvious in cases with many candidates, with thorough selection processes, and when longer and expensive training is needed before employees can begin to work. This is typical in the Nordic countries when recruiting new police or military personnel. Here, estimates suggest that it takes up to 10 years before police authorities achieve an effective return on their investments in new officers (Allisey et al. 2014). To avoid unwanted and expensive consequences associated with newly hired employees (e.g., low performance, illness, and premature turnover), employers may thus benefit from taking actions that help fostering the sustainability of newly recruited personnel, which in turn can enhance long-term organizational effectiveness.

When organizations identify a need for hiring new personnel, a traditional line of actions involve performing job analyses, which aim to identify any desirable key characteristics of new personnel, initiate actions to attract suitable candidates, and finally to identify the suitable candidates through using valid selection tools (Catano et al. 2013). Selection is thus a key process when hiring new personnel and aims to assess individual characteristics of importance for predicting applicants' future effectiveness as employees (Farr \& Tippins 2010). Numerous studies from the past century support the use of selection tools measuring individual characteristics including cognitive ability and personality to predict job performance (e.g., Schmidt \& Hunter 1998).

A perspective complementing the traditional selection studies is that of work socialization. Research on work socialization has shown that psychosocial working conditions (e.g., workload and feedback) during the introduction of newly hired personnel are important for future organizational outcomes reflecting person-environment fit (e.g., work-related attitudes, turnover, and health; Kammeyer-Mueller \& Wanberg 2003; Saks et al. 2007). This research belongs to another central tradition within work and organizational research that emphasizes psychosocial working conditions (e.g., workload and job control) to explain outcomes including work-related attitudes and health (e.g., Bakker \& Demerouti 2007; Hackman \& Oldham 1980; Karasek \& Theorell 1990). This suggests that sustainable recruitment is a process going beyond any formal selection decision to also include the period when newcomers start working and face their work tasks, get to know, and adapt to their jobs.

Drawing on the existing literature (cf. Di Fabio 2017; Eriksson et al. 2017), employers who strive for organizational sustainability seem likely to benefit from considering a variety of different factors. For instance, this includes considering both selection factors and psychosocial working conditions in their recruitment processes. Besides these factors being associated with job performance (e.g. Humphrey et al. 2007; Schmidt \& Hunter

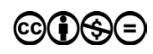


1998), they may also be linked to other attitudinal and behavioral outcomes reflecting sustainable recruitment. Among such outcomes are satisfaction with the job, a willingness to add some extra effort for the best of the organization, a willingness to stay in the job, and to maintain a good health, which signals an ability to handle psychological and physical job demands. However, the theoretical and empirical literature examining the relative importance of selection factors and psychosocial working conditions for outcomes reflecting sustainability is limited. In fact, most research focusing on motivational and behavioral organizational outcomes has examined the effects of individual dispositions and job characteristics separately, or given one or the other little attention (Barrick et al. 2013; Saks \& Ashforth 2000). This limitation applies to the selection literature, which typically neglects the influence of working conditions after having assessed the applicants (Ployhart \& Schneider 2012). This underscores the need to examine the relative importance of selection factors as compared to psychosocial working conditions in relation to outcomes reflecting sustainable recruitment. Such studies would improve the theoretical understanding of the process of sustainable recruitment and provide knowledge regarding efficient recruitment practices. In emphasizing the common good for individuals, organizations, and societies, such an integrative approach would also add to the holistic Nordic tradition of working life research (cf. Abrahamsson \& Johansson 2013), and provide knowledge on whether international research findings translate to the Nordic context.

\section{Selection factors}

While the specific selection tools used by employers vary, the literature suggests some general factors that are useful for employee selection (e.g., Kuncel et al. 2010). Such general selection factors include cognitive tests and personality inventories. Cognitive tests are typically assumed to measure general intelligence $(\mathrm{g})$ and have been found to be excellent predictors of job performance (Ones et al. 2010; Salgado et al. 2003; Schmidt \& Hunter 1998). Personality inventories have shown modest validity for predicting job performance (Salgado 2003). Yet, the Big Five personality dimensions conscientiousness and emotional stability have been found the most consistent predictors across different occupational groups (Barrick et al. 2001; Hurtz \& Donovan 2000; Salgado 1997). However, the combination of measures of cognitive ability and personality has been shown to be the most valid to predict job performance, and is consequently recommended for employee selection (Schmidt \& Hunter 1998). Still, adding complementary and valid information can be expected to improve further the prediction. For example, physical tests have been shown to predict performance in physically demanding tasks (Hogan 1991), and may add valuable information when selecting for jobs including such tasks.

In addition to the selection literature, other research fields have shown that individual characteristics are important for a range of outcomes. For instance, higher general intelligence has been associated with successfully dealing with demands of everyday life (Gottfredson 1997). Specifically, higher intelligence has been found to predict organizational citizenship behavior (Gonzales-Mulé et al. 2014), and better general health (Der et al. 2009), while negative associations have been found for job satisfaction (Ganzach 1998). Positive personality attributes tend to be associated with outcomes, including job satisfaction (Judge et al. 2002), organizational citizenship behavior (Borman et al. 2001; 
Chiaburu et al. 2011), retention (e.g., lower turnover intention; Barrick \& Mount 1996; Zimmerman 2008), health-related behaviors (e.g., less risky driving and less alcohol use; Bogg \& Roberts 2004), and longevity (Roberts et al. 2007), with conscientiousness and emotional stability being the most influential personality dimensions. Generally, physical fitness is only included when considered necessary for work performance (e.g., police or military), and has seldom been linked to other work-related outcomes. However, research has shown that physical fitness is associated with reduced stress and improved health (Gerber et al. 2010). Taken together, previous research suggests that individual characteristics typically covered by selection factors are valuable for a range of outcomes reflecting sustainability in working life, including job satisfaction, organizational citizenship behavior, retention, and health. However, previous research suggests that psychosocial working conditions are more important than individual characteristics (e.g., Miller et al. 2009; Saks \& Ashforth 2000).

\section{Psychosocial working conditions}

After a selection process, new employees enter their jobs and face their actual working situations with their psychosocial conditions. Extensive research has shown that psychosocial working conditions are important for various attitudinal, behavioral, and health-related outcomes (e.g., Humphrey et al. 2007). Several models, including the job demands-resources model (Bakker \& Demerouti 2007; Demerouti et al. 2001), the job characteristics model (Hackman \& Oldham 1980), the demand-control-support model (Karasek \& Theorell 1990), and the effort-reward imbalance model (Siegrist 1996), have been developed to explain the overall associations between psychosocial working conditions and various work-related and health-related outcomes. These models overlap, for instance in covering both job demands, including workload and emotional demands, and resources (or motivational characteristics), factors that are helpful in achieving work goals, stimulate personal growth, and reduce job demands, including job control (or autonomy) and social support (Bakker \& Demerouti 2007).

Moreover, existing research has shown that psychosocial working conditions may vary in importance when predicting different employee and organizational outcomes (Bakker et al. 2005; de Jonge et al. 1999). Overall, high demands have been associated with impaired health, while more resources, including for instance job control and support at work, have been related to positive work attitudes. The specific working conditions associated with such outcomes also tend to differ between occupations; for instance, both quantitative demands and emotional demands have been identified as important psychosocial factors among human service workers (Van Vegchel et al. 2004). A similar distinction has been suggested regarding organizational demands (e.g., work overload, poor management, and extensive administrative routines), and operational demands (e.g., exposure to danger and dealing with victims) constituting key psychosocial factors for police officers, for whom organizational demands are among the most important factors (Abdollahi 2002; Stinchcomb 2007; Waters \& Ussery 2007).

The present study focused primarily on investigating the overall importance of selection factors and factors of the psychosocial work environment for sustainable recruitment. We decided to use a limited number of specific factors previously identified as relevant for job satisfaction (e.g., Humphrey et al. 2007), organizational citizenship behavior 
(e.g., Podsakoff et al. 1996), turnover intention (e.g., Humphrey et al. 2007), and health (e.g., Kivimäki et al. 2012; Stansfeld \& Candy 2006). When selecting these specific psychosocial factors, we also considered the fact that the present study sample consisted of new police officers. This means that we made use of findings of relevant international policing research (e.g., Kop \& Euwema 2001; Martinussen et al. 2007; Miller et al. 2009; Noblet et al. 2009). Drawing on both the general and the occupation-specific literature, five different factors of the psychosocial work environment were included, namely workload, emotional demands, job control, feedback, and job challenge.

Specifically, considering the police literature, workload was assumed to represent organizational demands while emotional demands were assumed to represent operational demands (cf. Waters \& Ussery 2007). To understand police work, the rewarding aspects of policing, covering excitement, variation, and helping and dealing with people, have been suggested as important (e.g., Kop et al. 1999; Martinussen et al. 2007; Storch \& Pantzarella 1996). These rewarding aspects of policing have been found to influence the motivation to become a police officer (Raganella \& White 2004). Considering this, feedback (e.g., from supervisors, co-workers, or work), and job challenge (i.e., variation of work and opportunities for learning) were included to reflect the rewarding aspects of police work among newly hired officers. Also, police research has shown that job control (i.e., amount of autonomy and influence on how the work is carried out) is important for job satisfaction (Miller et al. 2009) and well-being (Noblet et al. 2009) among police officers.

\section{Aim and hypotheses}

The aim of the present study was to examine the relative importance of selection factors (general intelligence, personality, and physical fitness) and psychosocial working conditions (workload, emotional demands, job control, feedback, and job challenge) for four occupational outcomes (job satisfaction, organizational citizenship behaviour, occupational retention, and health) assumed to be indicative of sustainable recruitment. In predicting the outcomes, we used data including newly hired Swedish police officers. On the basis of existing theory and empirical research, we hypothesized selection factors to predict all four outcomes (H1), and psychosocial working conditions to add substantially over and above selection factors in predicting all outcomes (H2).

These general hypotheses were complemented with more specific predictions to clarify which of the specific predictors that were expected to be related to the specific outcomes associated with sustainable recruitment. We hypothesized general intelligence to be positively associated with organizational citizenship behavior and health, and negatively related to job satisfaction (H1a); in addition, we expected personality to predict all four outcomes (H1b), and physical fitness to predict health (H1c). Further, after controlling for selection factors, we hypothesized demands (i.e., workload and emotional demands) to be negatively related to health $(\mathrm{H} 2 \mathrm{a})$, while job resources (i.e., job control, feedback, and job challenge) were hypothesized to be the most influential in predicting job satisfaction, organizational citizenship behavior, and occupational retention $(\mathrm{H} 2 \mathrm{~b})$. In testing all hypotheses, we controlled for two individual demographic factors (gender and age) and two organizational factors (operational duty and size of police authority) assumed relevant for this sample of new police officers in Sweden (cf. Berg et al. 2005). 


\section{Method}

\section{Setting}

Sweden has one national police force, which in 2011 included 21 county police authorities. To become a police officer, applicants first have to pass an extensive admittance process for the basic police-training program. This basic training includes two years of academy training, at one of three sites, and an additional six months of field training at a county police authority. The field training includes a salaried temporary employment. Having completed their training, the new officers typically get employed as constables and generally work in operational duty.

\section{Participants and procedure}

The present study used data from two time-points, from the admittance process to the basic police training (Time 1; spring 2008) and from a 3.5-year follow-up when the participants had finalized their first year of employment (Time 2; end of 2011). Time 1 variables included individual demographics and selection factors, while Time 2 data included organizational demographics, psychosocial working conditions, and outcome variables.

At Time 1, after initial hurdles, 1429 applicants conducted final admission tests at the Swedish Defence Recruitment Agency (SDRA). Of these, 1344 (94\%) consented participation in the research project. At the SDRA, all participants received a survey, including demographics (e.g., place of residence) and a personality test, not included in the ordinary admission process. Almost all applicants passing the admission tests were offered a place at the basic police-training program. Of those not passing, most failed their selection interviews. The SDRA and the National Police Board provided data concerning the admittance process (e.g., test results).

In the fall 2008, 758 of the participants began their basic training. At Time 2 (i.e., at the end of 2011), 710 had finished their first year as police officers, and were in active duty, with most drop-outs being temporary (e.g., parental leave). All 710 participants in active duty at Time 2 received a follow-up survey and a written reminder, administered by the county police authorities. The participants returned their surveys in pre-paid envelopes to the SDRA. The effective sample in this study includes the 508 $(72 \%)$ officers who completed the follow-up survey. There were no differences in Time 1 variables between Time 2 respondents and nonrespondents. The mean age (2008) of the participants was 26 years (SD = 4), and $167(33 \%)$ were women. Ethical approval was obtained from the Regional Ethical Review Board in Stockholm.

\section{Measures}

Table 1 shows descriptive statistics for all measures. All index variables were calculated as averages, except for the personality variables, which were calculated as sums. Overall, reliabilities were satisfactory, with alphas $\geq .70$, exempting agreeableness and emotional demands $(\alpha=.66)$.

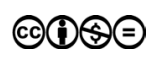




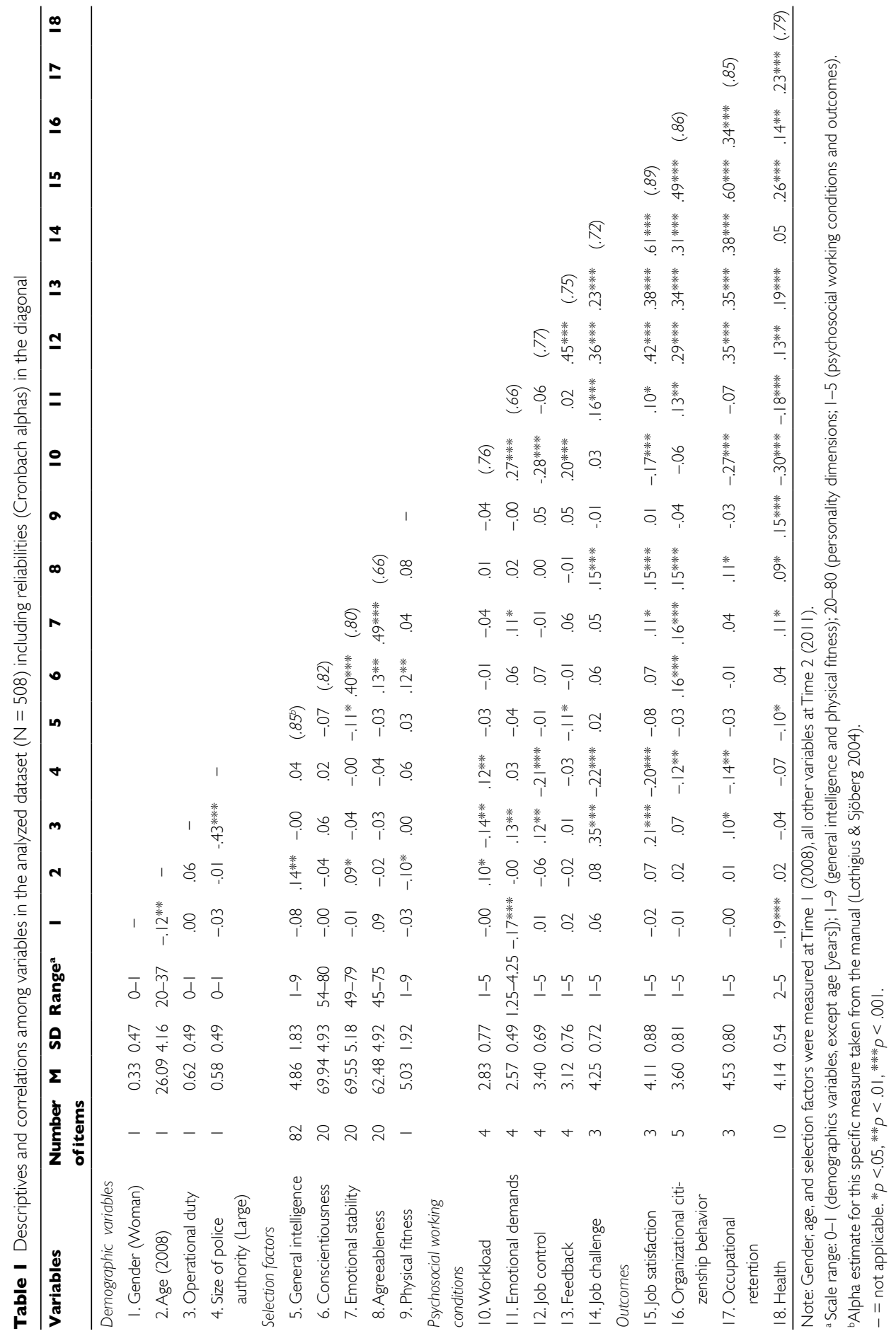


Outcomes. All four outcomes were measured at Time 2. Job satisfaction was measured with a Swedish version (Hellgren et al. 1997) of a three-item scale of job satisfaction (Brayfield \& Rothe 1951), including the affective dimension of job satisfaction. A sample item is: "I am satisfied with my job". Organizational citizenship behavior was measured with a five-item scale (Öhrming \& Sverke 2001), adapted to reflect willingness to exert extra effort for the best of the police (e.g., "I am prepared to work harder than what is expected of me, if it helps the police in being successful" and "I am motivated to work extra hard for the police"). Occupational retention was measured with a three-item scale of occupational turnover (Cohen 1998; Mobley et al. 1979), which was reversecoded to mirror retention. An item from this scale is: "I am actively looking for a job outside the police". Health was measured with a scale based on an instrument measuring subjective health complaints in the general population (Eriksen et al. 1998), including 10 reverse-coded items concerning the frequency of common health complaints (e.g., back-pain, headache, and problems sleeping). All outcome item responses were given on Likert scales, ranging from 1 (strongly disagree) to 5 (strongly agree), exempting subjective health complaints where items were answered on a five-point scale, ranging from 1 (never) to 5 (daily) and framed to cover the first year of work.

Selection factors. Five measures of three categories of selection factors, assessed at Time 1, were included. General intelligence (g) was measured by Uniq (Lothigius \& Sjöberg 2004), a test of six subtests developed for screening of police applicants in Sweden, with a composite score presented on a Stanine scale (see Annell et al. 2014). Three personality dimensions, conscientiousness, emotional stability, and agreeableness, were measured with Measuring Integrity (MINT), a Swedish integrity test (Sjöberg \& Sjöberg 2007). Each dimension included 20 items, with response alternatives ranging from 1 (strongly disagree) to 4 (strongly agree). Physical fitness was measured with a timed running test of $2 \mathrm{~km}$, with separate cut-offs for women (10 minutes, 15 seconds) and men (9 minutes, 30 seconds) (see Annell 2012). Here, the results were standardized by gender into a Stanine scale.

Psychosocial working conditions. Time 2 involved collecting self-ratings of five psychosocial factors of the work environment. Workload was assessed using a four-item scale, based on a measure of role overload (Beehr et al. 1976). A sample item is: "I often have too much to do in my job". Emotional demands were measured using a four-item scale (Sundin et al. 2008), adapted by us to fit the police context, regarding the frequency of having to face death, suffering individuals, aggressive people, and to fear for one's life. Job control was measured with a Swedish version (Sverke \& Sjöberg 1994) of a four-item scale (Hackman \& Oldham 1975). An example item is: "I can make my own decisions on how to organize my work". Feedback was measured with a four-item scale (Hackman \& Oldham 1975) with an example item being: "I have a pretty good idea of whether or not I am performing my job sufficiently well". Job challenge was measured using a three-item scale, reflecting variation and opportunities for learning at work (Hellgren et al. 1997). Two items are "My work is characterized by change and variation" and "I am learning new things all the time in my job". Item responses on measures of psychosocial factors were given on Likert scales, ranging from 1 (strongly disagree) to 5 (strongly agree), except for emotional demands where the response scale ranged from 1 (never) to 5 (daily) and included the first work year.

Demographics. Four demographic variables were included. Of these, two were individual variables measured at Time 1: gender $(1=$ woman, $0=$ man $)$ and age (in 2008). We 
also included two organizational variables measured at Time 2: size of police authority 2011 ( 1 = large -3 units with 2658 to 5667 employed officers; $0=$ small or medium -18 units with 114 to 793 employed police officers); operational duty, measured by a set of survey questions coded into a dichotomous variable $(1=$ mainly operational, i.e., patrolling, community policing, and traffic duties, $0=$ mainly other duties, i.e., investigations, and other nonoperational duties including communication center work).

\section{Data preparation and analyses}

In the original dataset $(\mathrm{N}=508),<1 \%$ were missing values. To avoid information loss by excluding 81 cases with incomplete data, missing values were imputed by applying the expectation-maximization (EM) method (Little \& Rubin 1987) in SPSS 21. All variables were used as predictors in the equation. The imputed dataset was then used for hierarchical multiple regression analyses to predict the four outcome variables (job satisfaction, organizational citizen behavior, occupational retention, and health), after first having been found to sufficiently meet statistical assumptions (Tabachnick \& Fidell 2013). The predictors were categorized into three blocks (demographic variables, selection factors, and psychosocial working conditions). These blocks were entered in three predetermined successive steps in order to investigate the relative importance of the predictors and the change in explained variance for each block of predictors.

\section{Results}

Table 2 presents the results of the hierarchical multiple regression analyses. The first predetermined step, which included the block of demographic variables (gender, age, operational duty, and size of police authority), accounted for $6 \%$ of the variance in job satisfaction, $1 \%$ in occupational retention, and $4 \%$ in health, but did not explain any significant variance in organizational citizenship behavior. New officers working at large police authorities were less satisfied with their jobs, reported lower levels of organizational citizenship behavior, lower intention to stay in the profession, and poorer health. Officers mainly working in operational duty were more satisfied with their jobs than those mainly working with other duties (e.g., investigations). Women reported poorer health than did men, while age did not predict any of the outcome variables.

Controlling for the first step, the adjusted difference in explained variance (Adj. $\Delta R^{2}$ ) showed that the second step of the analyses - including the block of selection factors (general intelligence, the personality dimensions conscientiousness, emotional stability, and agreeableness, and general physical fitness) - added $2 \%$ of explained variance in job satisfaction, $4 \%$ in organizational citizenship behavior, and $4 \%$ in health, but nothing in occupational retention. The total amount of explained variance in Step 2 did not exceed $8 \%$ in any outcome. All control variables that were significant predictors in the first step remained significant in the second step. Of the selection factors, general intelligence was negatively related to health, the two personality dimensions agreeableness and conscientiousness were associated with organizational citizenship behavior, while agreeableness also predicted job satisfaction and retention, and general physical fitness significantly predicted health. 
The third step, including the block of psychosocial working conditions while controlling for the previous steps, added $39 \%$ of explained variance in job satisfaction, $16 \%$ in organizational citizenship behavior, $24 \%$ in occupational retention, and $13 \%$ in health. The final models explained $47 \%$ of the variance in job satisfaction, $21 \%$ in organizational citizenship behavior, $26 \%$ in occupational retention, and $21 \%$ in health. Adding psychosocial working conditions to the equation, rendered nonsignificant several variables that were significant in Step 1 and Step 2; size of police authority became nonsignificant in predicting all four outcomes, agreeableness in predicting job satisfaction and occupational retention, and operational duty in predicting job satisfaction. The other significant relationships from Step 2 remained in Step 3. Two variables that were nonsignificant in previous steps became significant in Step 3: operational duty, which was negatively related to health, and general intelligence, which had a negative association with job satisfaction.

In the final model, job challenge was the strongest predictor of job satisfaction, followed by feedback and lower workload, with job control and a lower general intelligence also being significant predictors. Regarding organizational citizenship behavior, the strongest predictor was feedback, followed by job challenge and conscientiousness, with agreeableness and emotional demands also contributing positively to the prediction. The strongest predictor of occupational retention was job challenge, followed by a lower workload, and feedback. The strongest predictor of health of the new police officers was a lower workload, followed by being a man, less exposure to emotional demands, and a higher general physical fitness. A lower general intelligence, feedback, mainly having nonoperational duties, and job challenge were also significant predictors.

\section{Discussion}

The present study investigated the relative importance of selection factors and factors of the psychosocial work environment for four organizational outcomes - job satisfaction, organizational citizenship behavior, occupational retention, and health - that were assumed to indicate sustainable recruitment. Our first main hypothesis (H1) predicted the block of selection factors to explain variance in all four outcomes, after controlling for demographics (gender, age, size of authority, and operational duty). However, in this sample of new police officers in Sweden, this block explained additional variance only for three of the four outcomes, namely job satisfaction, organizational citizenship behavior, and health. Thus, H1 was only partially confirmed. Also, the contribution was rather marginal with the selection factors only adding up to $4 \%$ of explained variance in the outcomes. The psychosocial working conditions, in contrast, were shown to add between $13 \%$ (health) and $39 \%$ (job satisfaction) of the explained variance in the four outcomes, when controlling for demographics and selection factors. Thus, confirming our second main hypothesis $(\mathrm{H} 2)$, the main finding of the present study is that the psychosocial working conditions were more important for predicting the four outcomes than were the selection factors assessed 3.5 years before, during the admittance process to the basic police training. Thus, in underscoring the importance of psychosocial factors at work, as compared to selection factors, for long-term outcomes reflecting sustainable recruitment, this study adds to the existing working life research.

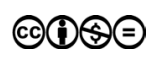




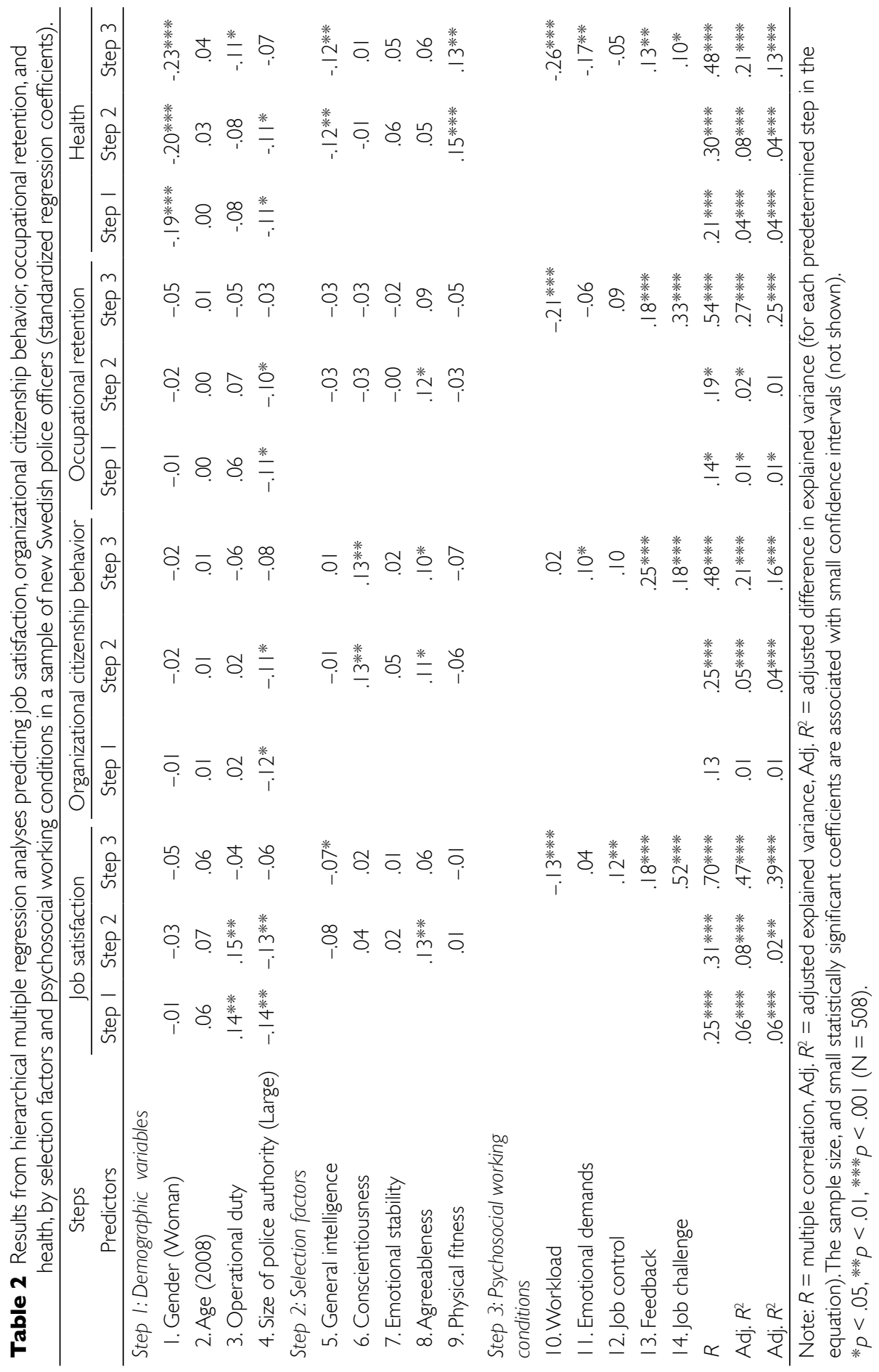




\section{Importance of selection factors}

Extensive research supports the importance of selection factors, including general intelligence and personality, for various outcomes (cf. Gonzales-Mulé et al. 2014; Gottfredson 1997; Schmidt \& Hunter 1998). In this study, however, the block of selection factors only contributed up to $4 \%$ of additional explained variance in the outcomes after controlling for demographics. While this figure is small, especially when considering previous research (e.g., Gonzales-Mule et al. 2014), it should be noted that the selection factors (i.e., individual characteristics) were measured a couple of years before the outcomes. Moreover, the final admission decision during the selection process was primarily based on other, but less valid, methods (e.g., interviews) than those investigated in this study (see Annell et al. 2015). Thus, the limited role of the selection factors is unlikely to result from restricted variation in these variables (cf. Table 1, with standard deviations and ranges). However, while the main hypotheses of this study focused on the blocks of selection factors and psychosocial working conditions, respectively, the standardized regression coefficients (see Table 2) provided additional information pertinent to sustainable recruitment and the more specific hypotheses.

$\mathrm{H} 1 \mathrm{a}$ predicted general intelligence to be positively associated with organizational citizenship behavior and health, and negatively related to job satisfaction. This hypothesis was only partially confirmed. While intelligence was negatively associated with job satisfaction (an effect that was significant only in Step 3), it did not predict organizational citizenship behavior and, contrary to predictions, the association with health was negative. These findings are opposed to previous research showing that intelligence is positively associated with organizational citizenship behavior (Gonzales-Mulé et al. 2014), and general health (Der et al. 2009). While general intelligence is typically argued to constitute a positive personal resource (cf. Gottfredson 1997), these unexpected findings not only suggest the opposite but also raise questions regarding how traditional police work fits individuals with a higher intellectual capacity and how police authorities handle these employees (e.g., by providing appropriate working conditions).

The second step of the regression analyses also showed that the personality dimensions predicted all outcomes but health. This means that $\mathrm{H} 1 \mathrm{~b}$, which stipulated that personality would predict all four outcomes, was partially supported. These results converge with existing research showing personality to be influential for job satisfaction (Judge et al. 2002), organizational citizenship behavior (Gonzales-Mulé et al. 2014), and the willingness to stay in a job (Zimmerman 2008). However, the importance of personality for health-related outcomes (cf. Roberts et al. 2007) was not replicated, which may relate to variations in the measurement of health. Specifically, the regression coefficients showed that higher agreeableness was related to higher job satisfaction, organizational citizenship behavior, and occupational retention. Additionally, high levels of conscientiousness were associated with organizational citizenship behavior. Although the bivariate correlations suggested associations between emotional stability and three of the outcomes, this personality dimension was nonsignificant throughout all regressions. These nonsignificant associations may not only relate to the sample of new police officers being highly selected on characteristics related to personality but may also reflect self-selection. Similar reasoning may explain why agreeableness, but neither conscientiousness nor emotional stability, as would be expected from previous research 
(see e.g., Judge et al. 2002), was the most important personality dimension in predicting the outcomes. Nonetheless, the findings indicate the value of agreeableness among newly hired police officers. Finally, in accordance with H1c and previous research (Gerber et al. 2010), physical fitness predicted health, but was nonsignificant in predicting the three other outcomes.

\section{Importance of psychosocial working conditions}

In line with previous research, our study emphasizes the importance of psychosocial working conditions for work-related and health-related outcomes (cf. Humphrey et al. 2007). Importantly, however, the present study provides a specific contribution in showing that the associations between psychosocial working conditions and outcome variables remained after controlling for a broad set of selection factors, including general intelligence, personality, and physical fitness.

The psychosocial factors of work investigated here were assumed to be relevant for new police officers. Accordingly, two factors, namely workload and emotional demands, assumed to reflect organizational and operational demands, respectively, were included to cover the demanding aspects of police work (cf. Waters \& Ussery 2007). In line with previous research showing demands to be associated with health problems (e.g., Bakker et al. 2005), and in accordance with H2a, we found a higher workload and a more frequent exposure to emotional demands to be the psychosocial factors most strongly associated with health complaints. Also, workload was negatively related to both job satisfaction and occupational retention, which is in line with the literature showing that organizational demands are more important than operational demands among police officers (e.g., Abdollahi 2002). Taken together, these findings underscore the value of ascertaining an appropriate workload among new personnel. A seemingly odd finding is that higher emotional demands predicted organizational citizenship behavior and that emotional demands had positive bivariate associations with job satisfaction. This may relate to the frequent exposure to emotionally demanding situations, which conforms to new officers' positive expectations of their occupation (cf. White \& Raganella 2004), and which, conversely to any unmet expectations (cf. Saks \& Ashforth 2000), may foster their work motivation. Another reason may involve officers reporting to be engaged in efforts for the best of the organization also being those who face the emotionally demanding aspects of police work.

$\mathrm{H} 2 \mathrm{~b}$ predicted the job resources (feedback, job challenge, and job control) to be the most important predictors of job satisfaction, organizational citizenship behavior, and occupational retention (cf. Bakker \& Demerouti 2007). In line with this hypothesis, feedback and job challenge, which cover rewarding aspects of policing (cf. Martinussen et al. 2007), were found to be positively related to these work-related outcomes, and also had positive associations with health. The present findings support viewing the psychosocial factors job challenge and feedback as essential for sustainable recruitment, and particularly so for new police officers. However, control, typically found an important predictor in organizational research (see Demerouti et al. 2001; Karasek \& Theorell 1990), was only significant for job satisfaction. A possible explanation may relate to the high associations between job control and the variables feedback and job challenge. 
Adding psychosocial working conditions in the regression analyses rendered nonsignificant some previously significant predictors. Among the selection factors, agreeableness became nonsignificant in the final models for both job satisfaction and occupational retention. While this may suggest that psychosocial factors have a mediating role between selection factors and outcomes, it also shows that the contribution of individual resources may decrease when taking psychosocial working conditions into account. Similarly, organizational demographics (i.e., operational duty and size of authority) that were significant in the earlier steps for job satisfaction, organizational citizenship behavior, and occupational retention, became nonsignificant. This demonstrates that a large share of the variance in the organizational demographics is related to psychosocial factors. Notably, adding psychosocial working conditions in the final models also rendered significant two previously nonsignificant predictors: operational duty (while size of authority became nonsignificant), which had a negative association with health, and general intelligence, which was negatively related to job satisfaction. This suggests complex relationships among the study variables.

The effects of demographics remained significant only in one of the final models, namely for health. In line with previous research (e.g., Eriksen et al. 1998), being a woman was associated with poorer health (here: more health complaints). A potential explanation lies in gender roles complicating the job situation for women who are police officers; specifically, the occupation is dominated by men and most people seem still to expect police officers to be men, which means that women have to balance conflicting expectations of being police officer and a woman, which may, add to their demands and pressure at work and thus influence their health (cf. Bloksgaard 2011; Falkenberg et al. 2015). The fact that operational duty was a significant negative predictor of health suggests that this factor reflects other aspects of interest. Physical demands may for instance be inherent in the operational duties of new police officers (e.g., shift work and wearing heavy equipment). Age was, somewhat surprisingly, nonsignificant in all models. This perhaps relates to underlying factors acting in opposite directions, with older officers having a family being more prone to stay in the profession, but also being more experienced, and having better opportunities if deciding to leave the police. However, it should be noted that the age span of the sample was restricted.

The findings of the present study show the importance of psychosocial working conditions for work-related attitudes and health among new officers. Although the direction of the relationships is theoretically supported, some of the common variance between work attitudes and health may relate to reciprocal relationships (see de Lange et al. 2004; Xanthopoulou et al. 2009). For instance, employees with poor health may perceive the workload as higher while those engaging in organizational citizenship behaviors get more feedback. Despite such complex potential underlying relationships, the present findings show clearly that psychosocial working conditions are important for sustainable recruitment. In all, the linkages with psychosocial factors, together with the rather limited contribution of selection factors, seem to suggest that the selection literature (e.g., Schmidt \& Hunter 1998) has been overly optimistic regarding the influence of general intelligence and personality, at least when considering the types of outcomes investigated in this study. Further, our findings imply that employers striving for sustainable recruitment need to focus on activities facilitating the entrance into organizations and subsequent professional careers, by providing sound psychosocial working conditions.

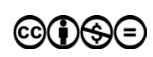




\section{Methodological considerations}

This study has not only several strengths but also some limitations. In striving to be parsimonious, and applying a holistic approach, we included a limited and balanced (i.e., equal number of selection factors and psychosocial factors) set of complementary predictors that were considered as the most relevant based on theory and empirical research. The sample size $(\mathrm{N}=508)$ and response rate among officers in active duty $(72 \%)$ were both satisfactory; however, our choice of predictors may have biased our findings, for instance by enlarging the differences between selection factors and psychosocial factors when predicting the outcome variables. While the findings could have been slightly different had additional selection factors or psychosocial factors been taken into account, it seems unlikely that doing so would have produced substantial changes in the main findings, particularly when considering the number of variables that were included and the consistency of the present findings, but also in view of previous findings (see Saks \& Ashforth 2000). Furthermore, the outcome variables were chosen to reflect various relevant aspects of sustainable recruitment. Clearly, it would have been informative to include a measure of task performance, but we chose to refrain from this in recognizing the well-known problems of accurately measuring police performance (e.g., Sanders 2008). However, it would be informative if future research included other outcomes.

While addressing a general issue of theoretical and practical concern, the present study included a sample of new police officers to investigate sustainable recruitment. Even though the police occupation has some rather unique attributes (e.g., the lawful use of deadly force), the occupation also shares important characteristics, such as the frequent exposure to emotional demands, with other occupational groups including occupations in health care and human services. Also, the study was based in Sweden. Considering cross-country variations, our findings would mainly hold for the Nordic countries, which share basic characteristics regarding police education and the context of the welfare state. Thus, it seems reasonable to assume a general validity of the present findings, while the possibilities to generalize to other occupations, and beyond the Nordic context, remain to be investigated. Also, the fact that the sample consisted of fairly young individuals in the beginning of their professional careers has to be considered, with the pattern of associations perhaps differing in other age groups.

Another potential limitation concerns causal inference. The selection factors were assessed 3.5 years prior to the outcomes. While this time-lag clearly speaks in favor of temporal precedence of the selection factors, it proves no causal relation (cf. Bollen 1989) but may still indicate the importance of selection factors in a longer perspective. In contrast, data on psychosocial factors and outcomes were collected at the same point in time. While this precludes conclusions about the causal role of working conditions, our findings follow both theoretical predictions (e.g., Bakker \& Demerouti 2007) and similar research findings spanning over 4 and 10 months (see Saks \& Ashforth 2000).

A related issue concerns common method variance. The design of the present study, with measures from two time points, separated individual demographics and selection factors from organizational demographics, psychosocial factors, and outcomes, thus making the impact of common method variance between selection factors and outcome variables a less plausible explanation underlying the findings. However, the strength of the relationships between psychosocial working conditions and outcomes may still 
have been inflated by common method variance. But controlling for individual differences reduced this plausibility. While the common method variance limitation is often exaggerated in organizational research (Spector 2006), the cross-sectional relationships between psychosocial working conditions and the outcomes make causal inferences inappropriate. Still, both theory and previous longitudinal research examining the effects of psychosocial factors at work on different organizational outcomes support the hypothesized direction of associations (e.g., de Lange et al. 2003; Mauno et al. 2007), although reciprocal relationships might explain some of the variance (see de Jonge et al. 1999). To examine further how selection factors and psychosocial factors relate to outcomes, it would be ideal to include complementary data sources (e.g., register data along with self-reports) and several follow-ups.

\section{Conclusion}

The present study approach combined two major, but rarely integrated research perspectives, namely those of selection factors and psychosocial factors at work. In confirming most, but not all hypotheses, this study of sustainable recruitment showed that psychosocial working conditions were more important than selection factors in predicting job satisfaction, organizational citizenship behavior, occupational retention, and health among new police officers in Sweden. Examining the relative importance of selection factors and psychosocial factors for outcomes reflecting occupational sustainability, this study contributes in clarifying aspects relating to sustainable recruitment and also provides support for improved recruitment practices. The associations between psychosocial factors on organizational outcomes among newly hired police officers suggest that, in practice, employers should make an effort to provide new personnel with sound working conditions that facilitate role fulfilment, a balanced workload along with rewarding aspects including feedback and opportunities for development. Focusing on work environment issues facilitating the entrance into organizational and occupational careers, employers seemingly have much to gain in avoiding unnecessary loss of productivity and competence, which add to the high costs of recruitment and training (cf. Casio \& Boudreau 2010). Considering this, employers should not only focus on organizational needs and desirable individual characteristics when performing job analyses but also take into account the needs and expectations of new personnel and how to satisfactorily meet these needs and expectations. This makes a contribution to a Nordic research line focusing on working life (cf. Abrahamsson \& Johansson 2013), and also extends this by combining two research perspectives thereby adding a new dimension of sustainability, namely sustainable recruitment with practical implications.

In showing the importance of psychosocial working conditions over selection factors for work-related attitudes and health, the present findings also raise an issue concerning recruitment practice and theory. Specifically, this related to whether the selection literature (e.g., Schmidt \& Hunter, 1998) has overstated the long-term importance of individual differences, including general intelligence and personality, when focusing primarily on performance while neglecting outcomes that reflect sustainable recruitment and the influence of the working conditions that newcomers meet when entering organizations. With selection often being a necessary part of recruitment, it should be 
emphasized that the measurement of individual differences for selection is valuable. But the present findings suggest that factors other than selection instruments may be central long-term indicators of how new employees adapt to their work situations. Moreover, and in line with results of organizational socialization research (e.g., Saks et al. 2007), our findings suggest that investments and expectations in selection practices also have to be realistic and complemented with the consideration of the working conditions of the newly hired employees to achieve sustainability. From a practical perspective, this may be important when recruiting for long-term organizational careers. To conclude, the findings show that traditional selection factors and psychosocial working conditions can be considered as complementary and essential for sustainable recruitment. This seems particularly the case for organizations having high costs of recruitment and training, including police organizations within Nordic countries.

\section{Acknowledgment}

This research was funded by the Swedish Defence Recruitment Agency (SDRA) and the Swedish Research Council for Health Working Life and Welfare (FORTE) and was conducted in cooperation between the SDRA, the National Police Board in Sweden, and Stockholm University. The research was carried out within Stockholm Stress Center, a FORTE center of excellence, which also provided financial support for Petra Lindfors and Göran Kecklund.

\section{References}

Abdollahi, M. K. (2002). Understanding police stress research, Journal of Forensic Psychology Practice 2(2): 1-24. doi: 10.1300/J158v02n02 01.

Abrahamsson, L., \& Johansson, J. (2013). One hundred years of inertia an exposé of the concept of the psychosocial work environment in Swedish policy and research, Nordic Journal of Working Life Studies 3(1): 4-30. doi: 10.19154/njwls.v3i1.2518.

Allisey, A. F., Noblet, A. J., Lamontagne, A. D., \& Houdmont, J. (2014). Testing a model of officer intentions to quit: the mediating effects of job stress and job satisfaction, Criminal Justice and Behavior 41(6): 751-771. doi: 10.1177/0093854813509987.

Annell, S. (2012). Vilka sökande antas till och påbörjar polisutbildningen? En demografisk beskrivning av 1429 sökande till polisutbildningen. En rapport från projektet Longitudinell validering av polisurvalet. [Which applicants are admitted to and begin police education? A demographic description of 1429 applicants to the police academy. A report from the project Longitudinal validation of the Swedish police selection; in Swedish] Teknisk rapport, Rekryteringsmyndighetens rapportserie, rapport $\mathrm{nr} 2$. Karlstad: Rekryteringsmyndigheten.

Annell, S., Lindfors, P., \& Sverke, M. (2015). Police selection - implications during training and early career, Policing: An International Journal of Police Strategies and Management 38(2): 221-238. doi: 10.1108/PIJPSM-11-2014-0119.

Annell, S., Sjöberg, A., \& Sverke, M. (2014). Use and interpretation of test scores from limited cognitive test batteries: how g + Gc can equal g, Scandinavian Journal of Psychology 55(5): 399-408. doi: 10.1111/sjop.12140.

Bakker, A. B., \& Demerouti, E. (2007). The Job Demands-Resources model: state of the art, Journal of Managerial Psychology 22(3): 309-328. doi: 10.1108/02683940710733115. 
Bakker, A. B., Demerouti, E., \& Euwema, M. C. (2005). Job resources buffer the impact of job demands on burnout, Journal of Occupational Health Psychology 10(2): 170-180. doi: 10.1037/1076-8998.10.2.170.

Barrick, M. R., \& Mount, M. K. (1996). Effects of impression management and self -deception on the predictive validity of personal constructs, Journal of Applied Psychology 81(3): 261-272. doi: 10.1037//0021-9010.81.3.261.

Barrick, M. R., Mount, M. K., \& Judge, T.A. (2001). Personality and performance at the beginning of the new millennium: What do we know and where do we go next? International Journal of Selection and Assessment 9(1/2): 9-30. doi: 10.1111/1468-2389.00160.

Barrick, M. R., Mount, M. K., \& Li, N. (2013). The theory of purposeful work behavior: the role of personality, higher-order goals, and job characteristics, Academy of Management Review 38(1): 132-153. doi: 10.5465/amr.10.0479.

Beehr, T. A., Walsh, J. T., \& Taber, T. D. (1976). Relationship of stress to individually and organizationally valued states: Higher order needs as a moderator, Journal of Applied Psychology 61(7): 41-47. doi: 10.1037/0021-9010.61.1.41.

Berg, A. M., Hem, E., Lau, B., Håseth, K, \& Ekeberg, Ø. (2005). Stress in the Norwegian police service, Occupational Medicine 55(2): 113-120. doi: 10.1093/occmed/kqi023.

Bloksgaard, L. (2011). Masculinities, femininities and work: the horizontal gender segregation in the Danish labour market, Nordic Journal of Working Life Studies 1(2): 5-21. doi: 10.19154/njwls.v1i2.2342.

Bogg, T., \& Roberts, B. W. (2004). Conscientiousness and health-related behaviors: a meta-analysis of the leading behavioral contributors to mortality, Psychological Bulletin 130(6): 887-919. doi: 10.1037/0033-2909.130.6.887.

Bollen, K. A. (1989). Structural equations with latent variables, New York, NY: Wiley. doi: 10.1002/9781118619179.

Borman, W. C., Penner, L. A., Allen, T. D., \& Motowidlo, S. J. (2001). Personality predictors of citizenship performance, International Journal of Selection and Assessment 9(1/2): 52-69. doi: 10.1111/1468-2389.00163.

Brayfield, A. H., \& Rothe, H. F. (1951). An index of job satisfaction, Journal of Applied Psychology 35(5): 307-311. doi: 10.1037/h0055617.

Cascio, W. F., \& Boudreau, J. (2010). Investing in People: Financial Impact of Human Resource Initiatives ( $2^{\text {nd }}$ ed.), Upper Saddle River, New Jersey: FT Press.

Catano, V. M., Wiesner, W. H., \& Hackett, R. D. (2013). Recruitment and Selection in Canada ( $5^{\text {th }}$ ed.), Toronto: Nelson Education Ltd.

Chiaburu, D. S., Oh, I.-S., Berry, C. M., Li, N., \& Gardner, R. G. (2011). The five-factor model of personality traits and organizational citizenship behaviors: a meta-analysis, Journal of Applied Psychology 96(6): 1140-1166. doi: 10.1037/a0024004.

Cohen, A. (1998). An examination of the relationship between work commitment and work outcomes among hospital nurses, Scandinavian Journal of Management 14(1/2): 1-17. doi: 10.1016/s0956-5221(97)00033-x.

de Jonge, J., Mulder, M. J. G. P., \& Nijhuis, F. J. N. (1999). The incorporation of different demand concepts in the job demand-control model: effects on health care professionals, Social Science \& Medicine 48(9): 1149-1160. doi: 10.1016/s0277-9536(98)00429-8.

de Lange, A. H., Taris, T. W., Kompier, M. A. J., Houtman, I. L. D., \& Bongers, P. M. (2003). "The very best of the millennium": Longitudinal research and the demandcontrol-(support) model, Journal of Occupational Health Psychology 8(4): 282-305. doi: 10.1037/1076-8998.8.4.282.

de Lange, A. H., Taris, T. W., Kompier, M. A. J., Houtman, I. L. D., \& Bongers, P. M. (2004). The relationships between work characteristics and mental health: examining normal, reversed and reciprocal relationships in a 4-wave study, Work \& Stress 18(2): 149-166. doi: $10.1080 / 02678370412331270860$. 
Demerouti, E., Bakker, A. B., Nachreiner, F., \& Schaufeli, W. B. (2001). The job demandsresources model of burnout, Journal of Applied Psychology 86(3): 499-512. doi: 10.1037//0021-9010.86.3.499.

Der, G., Batty, G. D., \& Deary, I. J. (2009). The association between IQ in adolescence and a range of health outcomes at 40 in the 1979 US National Longitudinal Study of Youth, Intelligence 37(6): 573-580. doi: 10.1016/j.intell.2008.12.002.

Di Fabio, A. (2017). The psychology of sustainability and sustainable development for wellbeing in organizations, Frontiers in Psychology 8: 1-7. doi: 10.3389/fpsyg.2017.01534.

Eriksen, H. R., Svendsrød, R., Ursin, G., \& Ursin, H. (1998). Prevalence of subjective health complaints in the Nordic European countries in 1993, The European Journal of Public Health 8(4): 294-298. doi: 10.1093/eurpub/8.4.294.

Eriksson, A., Orvik, A., Strandmark, M., Nordsteien, A., \& Torp. S. (2017). Management and leadership approaches to health promotion and sustainable workplaces: a scoping review, Societies 7(14): 1-17. doi: 10.3390/soc7020014.

Falkenberg, H., Näswall, K., Lindfors, P., \& Sverke, M. (2015). Working in the same sector, in the same organization and in the same occupation: Similarities and differences between women and men physicians' work climate and health complaints, Nordic Journal of Working Life Studies 5(4): 67-84. doi: 10.19154/njwls.v5i4.4844.

Farr, J. L., \& Tippins, N. T. (2010). Handbook of employee selection. An introduction and overview. In J. F. Farr \& N. Tippins. (Eds.), Handbook of Employee Selection (pp. 1-6), London: Routledge. doi: 10.4324/9780203809808.

Ganzach, Y. (1998). Intelligence and job satisfaction, Academy of Management Journal 41(5): 526-539. doi: 10.2307/256940.

Gerber, M. Kellmann, M., Hartmann, T., \& Pühse, U. (2010). Do exercise and fitness buffer against stress among Swiss police and emergency service officers? Psychology of Sport and Exercise 11(4): 286-294. doi: 10.1016/j.psychsport.2010.02.004.

Gonzalez-Mulé, E., Mount, M. K., \& Oh, I.-S. (2014). A meta-analysis of the relationship between general mental ability and nontask performance, Journal of Applied Psychology 99(6): 1222-1243. doi: 10.1037/a0037547.

Gottfredson, L. S. (1997). Why g matters: The complexity of everyday life, Intelligence 24(1): 79-132. doi: 10.1016/s0160-2896(97)90014-3.

Griffeth, R. W., \& Hom, P. W. (2001). Retaining Valued Employees. Thousand Oaks, CA: SAGE Publications, Inc. doi: $10.4135 / 9781452231242$.

Hackman, J. R., \& Oldham, G. R. (1975). Development of the job diagnostic survey, Journal of Applied Psychology 60(2): 159-170. doi: 10.1037/h0076546.

Hackman, J. R., \& Oldham, G. R. (1980). Work Redesign, Reading, MA: Addison Wesley.

Hellgren, J., Sjöberg, A., \& Sverke, M. (1997). Intention to quit: effects of job satisfaction and job perceptions. In F. Avallone, J. Arnold, \& K. de Witte (Eds.), Feelings Work in Europe (pp. 415-423). Milano: Guerini.

Hogan, J. C. (1991). Physical abilities. In M. D. Dunnette \& L. M. Hough (Eds.), Handbook of Industrial and Organizational Psychology (Vol. 2, pp. 753-831), Palo Alto, CA: Consulting Psychologist Press.

Humphrey, S. E., Nahrgang, J. D., \& Morgeson, F. P. (2007). Integrating motivational, social, and contextual work design features: a meta-analytic summary and theoretical extension of the work design literature, Journal of Applied Psychology 92(5): 1332-1356. doi: 10.1037/0021-9010.92.5.1332.

Hurtz, G. M., \& Donovan, J. J. (2000). Personality and job performance: the big five revisited, Journal of Applied Psychology 85(6): 869-879. doi: 10.1037//0021-9010.85.6.869.

Judge, T. A., Heller, D., \& Mount, M. K. (2002). Five-factor model of personality and job satisfaction: a meta-analysis, Journal of Applied Psychology 87(3): 530-541. doi: 10.1037//0021-9010.87.3.530. 
Kammeyer-Mueller, J. D., \& Wanberg, C. R. (2003). Unwrapping the organizational entry process: disentangling multiple antecedents and their pathways to adjustment, Journal of Applied Psychology 88(5): 779-794. doi: 10.1037/0021-9010.88.5.779.

Karasek, R., \& Theorell, T. (1990). Healthy work: Stress, Productivity, and the Reconstruction of Working Life, New York: Basic Books.

Kira, M., van Eijnatten, F. M., \& Balkin, D. B. (2010). Crafting sustainable work: development of personal resources, Journal of Organizational Change Management 23(5): 616-632. doi: 10.1108/09534811011071315.

Kivimäki, M., Nyberg, S. T., Batty, G.D., Fransson, E. I., Heikkilä, K., et al. (2012). Job strain as a risk factor for coronary heart disease: a collaborative meta-analysis of individual participant data, The Lancet 380(9852): 1491-1497. doi: 10.1016/s01406736(12)60994-5.

Kop, N., \& Euwema, M. C. (2001). Occupational stress and violence in Dutch policing, Criminal Justice and Behavior 28(5): 631-652. doi: 10.1177/009385480102800505.

Kop, N., Euwema, M. C., \& Schaufeli, W. (1999). Burnout, job stress and violent behaviour, Work and Stress 13(4): 326-340. doi: 10.1080/02678379950019789.

Little, R. J. A., \& Rubin, D. B. (1987). Statistical Analysis with Missing Data, New York: Wiley.

Kuncel, N. R., Ones, D. S., \& Sackett, P. R. (2010). Individual differences as predictors of work, educational, and broad life outcomes, Personality and Individual Differences 49(4): 331-336. doi: 10.1016/j.paid.2010.03.042.

Lothigius, J., \& Sjöberg, A. (2004) UNIQ. Version 2.0 [In Swedish]. Teknisk rapport, Stockholm: Psykologiförlaget AB.

Martinussen, M., Richardsen, A. M., \& Burke, R. J. (2007). Job demands, job resources, and burnout among police officers, Journal of Criminal Justice 35(3): 239-249. doi: 10.1016/j.jcrimjus.2007.03.001.

Mauno, S., Kinnunen, U., \& Ruokolainen, M. (2007). Job demands and resources as antecedents of work engagement: a longitudinal study, Journal of Vocational Behavior 70(1): 149-171. doi: 10.1016/j.jvb.2006.09.002.

Miller H. A., Mire, S., \& Kim, B. (2009). Predictors of job satisfaction among police officers: does personality matter? Journal of Criminal Justice 37(5): 419-426. doi: 10.1016/j. jcrimjus.2009.07.001.

Mobley, W. H, Griffeth, R. W, Hand, H. H., \& Meglino, B. M. (1979). Review and conceptual analysis of the employee turnover process, Psychological Bulletin 86(3): 493-522. doi: 10.1037//0033-2909.86.3.493.

Noblet, A., Rodwell, J., \& Allisey, A. (2009). Job stress in the law enforcement sector: comparing the linear, non-linear and interaction effects of working conditions. Stress and Health 25(1): 111-120. doi: 10.1002/smi.1227.

Öhrming, J., \& Sverke, M. (2001). Bolagisering av S:t Göran: En proaktiv organisering [Hospital corporatization: Proactive organization; In Swedish], Lund: Studentlitteratur.

Ones, D. S., Dilchert S., Viswesvaran, C., \& Salgado, J. F. (2010). Cognitive abilities. In J. F. Farr \& N. Tippins, Handbook of Employee Selection (pp. 255-275), London: Routledge. doi: 10.4324/9780203809808.

Ployhart, R. E., \& Schneider, S. (2012). The social and organizational context of personnel selection. In N. Schmitt (Ed.), The Oxford Handbook of Personnel Assessment and Selection (pp. 48-67), New York: Oxford University Press. doi: 10.1093/oxfordhb/9780199732579.013.0004.

Podsakoff, P. M., McKenzie, S. B., \& Bommer, W. H. (1996). Meta-analysis of the relationships between Kerr and Jermier's substitutes for leadership and employee job attitudes, role perceptions, and performance, Journal of Applied Psychology 81(4): 380-399. doi: 10.1037//0021-9010.81.4.380. 
Raganella, A. J., \& White, M. D. (2004). Race, gender, and motivation for becoming a police officer: implications for building a representative police department, Journal of Criminal Justice 32(6): 501-513. doi: 10.1016/j.jcrimjus.2004.08.009.

Roberts, B. W., Kuncel, N. R., Shiner, R., Caspi, A., \& Goldberg, L. R. (2007). The power of personality: the comparative validity of personality traits, socioeconomic status, and cognitive ability for predicting important life outcomes, Perspectives on Psychological Science 2(4): 313-345. doi: 10.1111/j.1745-6916.2007.00047.x.

Saks, A. M., \& Ashforth, B. E. (2000). The role of dispositions, entry stressors, and behavioral plasticity theory in predicting newcomers' adjustment to work, Journal of Organizational Behavior 21(1): 43-62. doi: 10.1002/(SICI)1099-1379(200002)21:1<43::AIDJOB985>3.0.CO;2-W.

Saks, A. M., Uggerslev, K. L., \& Fassina, N. E. (2007). Socialization tactics and newcomer adjustment: a meta-analytic review and test of a model, Journal of Vocational Behavior 70(3): 413-446. doi: 10.1016/j.jvb.2006.12.004.

Salgado, J. F. (1997). The five factor model of personality and job performance in the European Community, Journal of Applied Psychology 82(1): 30-43. doi: 10.1037//00219010.82.1.30.

Salgado, J. F. (2003). Predicting job performance using FFM and non-FFM personality measures, Journal of Occupational and Organizational Psychology 76(3): 323-346. doi: 10.1348/096317903769647201.

Salgado, J. F., Anderson, N., Moscoso, S., Bertua, C., De Fruyt, F., \& Rolland, J. P. (2003). A meta-analytic study of general mental ability validity for different occupations in the European community, Journal of Applied Psychology 88(6): 1068-1081. doi: 10.1037/00219010.88.6.1068.

Sanders, B. A. (2008). Using personality traits to predict police officer performance, Policing: An International Journal of Police Strategies and Management 31(1): 129-147. doi: $10.1108 / 13639510810852611$.

Schmidt, F. L., \& Hunter, J. E. (1998). The validity and utility of selection methods in personnel psychology: practical and theoretical implications of 85 years of research findings, Psychological Bulletin 124(2): 262-274. doi: 10.1037//0033-2909.124.2.262.

Siegrist, J. (1996). Adverse health effects of high effort-low reward conditions, Journal of Occupational Health Psychology 1(1): 27-41. doi: 10.1037/1076-8998.1.1.27.

Sjöberg, S., \& Sjöberg, A. (2007). MINT Measuring Integrity - Manual [Swedish version], Stockholm: Assessio International.

Spector, P. E. (2006). Method variance in organizational research - truth or urban legend? Organizational Research Methods 9(2): 221-232. doi: 10.1177/1094428105284955.

Stansfeld, S., \& Candy, B. (2006). Psychosocial work environment and mental health - a meta-analytic review, Scandinavian Journal of Work, Environment \& Health 32(6): 443-462. doi: $10.5271 /$ sjweh.1050.

Stinchcomb, J. B. (2007). Searching for stress in all the wrong places: combating chronic organizational stressors in policing. Police Practice and Research: An International Journal 5(3): 259-277. doi: 10.1080/156142604200227594.

Storch, J., \& Panzarella, R. (1996). Police stress: state anxiety in relation to occupational and personal stressors, Journal of Criminal Justice 24(2): 99-107. doi: 10.1016/00472352(95)00058-5.

Sundin, L., Hochwälder, J., \& Bildt, C. (2008). A scale for measuring specific job demands within the health care sector: development and psychometric assessment, International Journal of Nursing Studies 45(6): 914-923. doi: 10.1016/j.ijnurstu.2007.03.006.

Sverke, M., \& Sjöberg, A. (1994). Dual commitment to company and union in Sweden: an examination of predictors and taxonomic split methods, Economic and Industrial Democracy 15(4): 531-564. doi: 10.1177/0143831x94154003. 
Tabachnick, B. G., \& Fidell, L. S. (2013). Using Multivariate Statistics (6th ed.). Boston, Massachusetts: Pearson.

Van Vegchel, N., de Jonge, J., Söderfeldt, M., Dormann, C., \& Schaufeli, W. (2004). Quantitative versus emotional demands among Swedish human service employees: moderating effects of job control and social support, International Journal of Stress Management 11(1): 21-40. doi: 10.1037/1072-5245.11.1.21.

Waters, J. A., \& Ussery, W. (2007). Police stress: history, contributing factors, symptoms, and interventions, Policing: An International Journal of Police Strategies and Management 30(2): 169-188. doi: 10.1108/13639510710753199.

Xanthopoulou, D., Bakker, A. B., Demerouti, E., \& Schaufeli, W. B. (2009). Reciprocal relationships between job resources, personal resources, and work engagement, Journal of Vocational Behavior 74(3): 235-244. doi: 10.1016/j.jvb.2008.11.003.

Zimmerman, R. D. (2008). Understanding the impact of personality traits on individuals' turnover decisions: a meta-analytic path model, Personnel Psychology 61(2): 309-348. doi: $10.1111 / \mathrm{j} .1744-6570.2008 .00115 . \mathrm{x}$. 